\title{
Life history, biomass and production of Coronatella rectangula (Branchiopoda, Anomopoda, Chydoridae) from Minas Gerais
}

\author{
Thais Viti ${ }^{1}$, Célio Wisniewski ${ }^{2}$, Tereza Cristina Orlando ${ }^{2} \&$ Maria José dos Santos-Wisniewski ${ }^{2}$
}

\author{
1. Programa de Pós-Graduação em Ecologia e Tecnologia Ambiental, Universidade Federal de Alfenas (UNIFAL), Rua Gabriel Monteiro da Silva, 714, 37130-000 Alfenas, MG, Brasil. \\ (thais_viti@hotmail.com) \\ 2. Universidade Federal de Alfenas (UNIFAL), Instituto de Ciências da Natureza, Rua Gabriel Monteiro da Silva, 714, 37130-000 Alfenas, MG, Brasil.
}

\begin{abstract}
Species of Chydoridae provide the main diversity of the Cladocera. These organisms have been the subject of many studies; some dealing with their role in energy flow in aquatic ecosystems, since they inhabit the littoral region of water bodies which undergo the first impacts from anthropic activities. The aim of this study is to increase knowledge about the life cycle of Coronatella rectangula (Sars, 1861), a species found in several water bodies in the state of Minas Gerais, Brazil. The life cycle was determined by the culture of parthenogenetic females under controlled conditions in the laboratory. Experimental cultures were maintained in growth chambers at a constant temperature of $23.6( \pm 0.5)^{\circ} \mathrm{C}$,

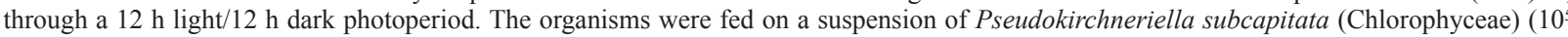
cells. $\mathrm{mL}^{-1}$ ), and $0.02 \mathrm{~mL}$ of a mixed suspension of yeast and fish ration added per organism in equal proportions (1:1). Fifty parthenogenetic females with eggs were isolated and maintained until they produced neonates. Thirty of these neonates that had less than 24 hours were put in polypropylene bottles of $50 \mathrm{~mL}$ and kept in a germination chamber. These organisms were observed daily to obtain the parameters of the life cycle. Biomass and secondary production were also calculated. The embryonic development time of the specimens of C. rectangula was $1.68( \pm 0.13)$ days and the time to reach primipara, was $2.48( \pm 0.45)$ days. The mean fecundity of $C$. rectangula was two eggs/female/brood and the total number of eggs produced by the female during its life cycle was 27.8 eggs. During the whole life cycle, specimens of $C$. rectangula had a maximum of 14 seedlings, with two instars in the juvenile stage. Total biomass for $C$. rectangula was $36.66 \mu \mathrm{gDW} \cdot \mathrm{m}^{-3}(9.83$ for the juvenile stage and 26.82 $\mu \mathrm{gDW} . \mathrm{m}^{-3}$ for adults), and secondary production was $12.10 \mu \mathrm{gDW} \cdot \mathrm{m}^{-3} \cdot$ day $^{-1}\left(8.34 \mu \mathrm{gDW} \cdot \mathrm{m}^{-3}\right.$. day $^{-1}$ for egg production and $3.76 \mu \mathrm{gDW} . \mathrm{m}^{-3} . \mathrm{day}^{-1}$ for the juvenile stage)
\end{abstract}

KEYWORDS. Life cycle, Cladocera, littoral region, phytophilous organisms.

RESUMO. História de vida, biomassa e produção de Coronatella rectangula (Branchiopoda, Anomopoda, Chydoridae) de Minas Gerais. As espécies de Chydoridae correspondem a maior diversidade de Cladocera. Estes organismos tem sido objeto de diversos estudos, com enfoque para seu papel no fluxo de energia nos ambientes aquáticos, uma vez que habitam a região litoral dos corpos d'água que recebem os primeiros impactos decorrentes das atividades antrópicas. O objetivo deste estudo é conhecer o ciclo de vida de Coronatella rectangula (Sars, 1861), espécie encontrada em vários corpos d'água de Minas Gerais, Brasil. O ciclo de vida foi determinado através do cultivo em laboratório de fêmeas partenogenéticas, sob condições controladas. Culturas experimentais foram mantidas em câmaras de germinação com temperatura de $23,6( \pm 0,5)^{\circ} \mathrm{C}$ e fotoperíodo constante $\left(12 \mathrm{~h}\right.$ claro $/ 12 \mathrm{~h}$ escuro). Os organismos foram alimentados com uma suspensão de $10^{5}$ células. $\mathrm{mL}^{-1} \mathrm{da}$ clorofícea Pseudokirchneriella subcapitata e $0,02 \mathrm{~mL}$ de uma suspensão mista de levedura e ração de peixe em igual proporção (1:1). Cinquenta fêmeas com ovos foram isoladas e mantidas até a produção de neonatas. Trinta neonatas com menos de 24 horas foram colocadas em potes de $50 \mathrm{~mL}$ de polipropileno e conservadas em câmara de germinação. Estes organismos foram observados diariamente para obtenção dos parâmetros do ciclo de vida. Foram calculadas também a biomassa e a produção secundária. $\mathrm{O}$ tempo de desenvolvimento embrionário dos espécimes de $C$. rectangula foi de $1,68( \pm 0,13)$ dias e a idade da primípara (tempo de desenvolvimento pós- embrionário) foi de $2,48( \pm 0,45)$ dias. A fecundidade média foi de 2 ovos/fêmea/ninhada e o número total de ovos produzidos durante todo o ciclo de vida foi de 27,8 ovos. Durante todo o ciclo de vida, espécimes de $C$. rectangula tiveram um máximo de 14 mudas, sendo dois ínstares no estágio juvenil. A biomassa total de $C$. rectangula foi de $36,66 \mu \mathrm{gPS} \cdot \mathrm{m}^{-3}\left(9,83 \mu \mathrm{gPS} \cdot \mathrm{m}^{-3}\right.$ para o estágio juvenil e $26,82 \mu \mathrm{gPS} \cdot \mathrm{m}^{-3}$ para adultos $)$, e a produção secundária foi de $12,10 \mu \mathrm{gPS} \cdot \mathrm{m}^{-3} \cdot \mathrm{dia}^{-1}(8,34$ $\mu \mathrm{gPS} . \mathrm{m}^{-3} \cdot$ dia $^{-1}$ a produção de ovos e $3,76 \mu \mathrm{gPS} \cdot \mathrm{m}^{-3} \cdot \mathrm{dia}^{-1}$ para o estágio juvenil).

PALAVRAS-CHAVE. Ciclo de vida, Cladocera, região litoral, organismos fitófilos.

Chydoridae corresponds to approximately $70 \%$ of known species of Cladocera and the major diversity of this group (ELMOOR-LoureIro, 2000; Forró et al., 2008). This family inhabits littoral regions, a transition between the aquatic and terrestrial environments that allow the occurrence of many different niches. The richness of littoral regions is mainly due to cladoceran species, which serve as filters, scrapers or collectors of organic materials. Chydoridae are phytophylous organisms and usually live associated with macrophytes, periphyton and sediment (SANTOS-WISNIEWSKI et al., 2002), where they use particles present in sediment or suspended vegetation, and exploit several microhabitats created by macrophytes (NogueIra et al., 2003; Sousa \& Elmoor-Loureiro, 2008; SoAres \& ElmoorLOUREIRO, 2011). Phytophylous organisms have been the subject of various studies, dealing also with their role in energy flow in aquatic ecosystems, since they inhabit the littoral region of water bodies and undergo the first impacts resulting from anthropic activities (ElMOorLOUREIRO, 2007).

Despite the importance of knowing about the biology and ecology of the species of Chydoridae, most studies about their life cycle have been carried out with limnetic cladocerans. Some of these studies in Brazil were with species of Daphnidae (RochA \& Matsumura-Tundisi, 1990; Fonseca, 1998; Rietzler, 1998; Fonseca \& Rocha, 2004; MaiaBarbosa \& Bozelli, 2006; Santos et al., 2006;), Sididae (Rietzler, 1998; Freitas \& Rocha, 2006; Maia-Barbosa \& Bozelli, 2006), Bosminidae (Maia-Barbosa \& Bozelli, 2006; Melão \& Rocha, 2006) and Moinidae (KePPler \& HARdy, 2002; MAIABarbosa \& Bozelli, 2006). 
Studies on the life cycle of littoral species in Brazil have been carried out with Chydoridae, Macrothricidae and Ilyocryptidae. For the latter two families, there have been studies on Macrothrix rosea (Jurine, 1820) (Melão, 1999), Macrothrix pectinata (Smirnov, 1976) (Melão, 1999), Macrothrix flabelligera Smirnov, 1992 (GunTZEL et al., 2003) and Ilyocryptus spinifer Herrick, 1882 (Melão, 1999). For Chydoridae, life cycle studies have been done for Chydorus dentifer Daday, 1905 and Acroperus harpae Baird, 1843 by MeLÃo (1999) and the distribution and life cycle of Chydorus pubescens Sars, 1901 by SANTOS-WISNIEWSKI et al. (2006).

The Coronatella rectangula (Sars, 1861) belongs to Chydoridae, subfamily Aloninae. It was previously included in the genus Alona Baird, 1843 and, after reviewing, it was relocated in Coronatella Dybowski \& Grochowski, 1894, because synapomorphies were found which differentiated Alona rectangula from the true Alona. According to Smirnov (1974), C. rectangula has a cosmopolitan distribution. For VAN Damme \& Dummont (2008) it is probably restricted to Western Europe and the populations recorded outside this region need to be confirmed and may be considered cryptic species. VAN DAMme et al. (2010) consider that the true $C$. rectangula is restricted to Eurasia. In Europe, it forms a complex of species and outside very similar species are observed. In Brazil, there are records in several states, but the status of the Brazilian population is uncertain (SINEv, 2001; ELMOOR-LOUREIRO, 2010). Outside Europe, the status of the registered $C$. rectangula population is highly variable, so morphological and molecular studies will help to clear up these uncertain taxonomic doubts (VAN DAMME et al., 2010).

The knowledge of the life cycle of species of the zooplankton community is essential for studies on dynamics of population and secondary production. Some factors affect the development and reproduction of cladocerans and, consequently, their secondary production, especially the use of organic matter by consumers, which is measured by increasing the biomass by time unit (SANTOS et al., 2010). The reproduction of Cladocera occurs most of the time asexually, by parthenogenesis. In this type of reproduction, diploid eggs are deposited in the incubation chamber where they undergo rapid division. After about two days, neonates are released to the environment in a form similar to that of the adult body, without larval stages. Sexual reproduction can occur when environmental conditions are unfavorable (ELMOOR-Loureiro, 1997).

There is no record of studies on the life cycle of this species and knowledge about the life cycle of littoral cladocerans is scarce. The aim of this study is to further the knowledge about the life cycle of C. rectangula, species found in several water bodies in the state of Minas Gerais, Brazil.

\section{MATERIALS AND METHODS}

Samples from 39 water bodies were collected, including among them the EPAMIG pond in the Lambari District, in the southern state of Minas Gerais,

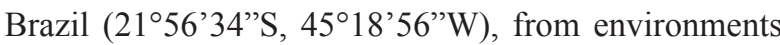
where organisms were obtained for laboratory cultures. The species was recorded in eight of the 39 water bodies sampled in the global project: Nova Floresta

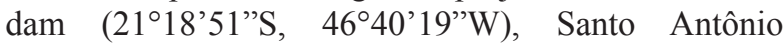
Pitangueiras pond $\left(21^{\circ} 21^{\prime} 16^{\prime \prime} \mathrm{S}, 46^{\circ} 38^{\prime} 6^{\prime \prime} \mathrm{W}\right)$, Santa

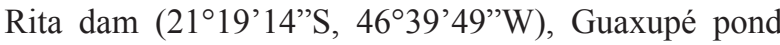

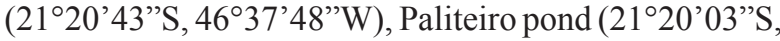

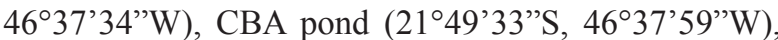

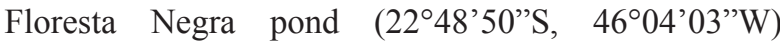

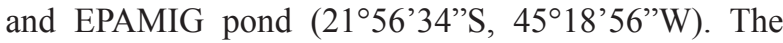
organisms for culture were collected on July $7^{\text {th }}, 2010$, from the littoral region, by vertical and horizontal hauls using a zooplankton net of $68 \mu \mathrm{m}$ mesh size. Samples for biomass and secondary production analysis were collected by filtering $100 \mathrm{~L}$ of water, using the same net, and they were preserved in $4 \%$ formaldehyde and sucrose added, so as to not shed the eggs.

The $\mathrm{pH}$, electrical conductivity, concentration of dissolved oxygen and water temperature were measured using a multisensory, mod. Horiba U-22. The trophic state index (TSI) was calculated (TOLEDo et al., 1983) using data of chlorophyll a (GolTERMAN et al., 1978), total phosphorus and total dissolved phosphorus (MurPhy \& Riley, 1962).

The identification and description of $C$. rectangula was carried out according to ELMOOR-LOUREIRO (1997, 2010), Van Damme \& Dummont (2008) and Van Damme et al. (2010).

In the laboratory, parthenogenetic females were isolated and placed in $2 \mathrm{~L}$ beakers containing reconstituted water, according to ABNT (2004), and the individuals acclimatized for about 10 generations (30 days). Experimental cultures were maintained in growing chambers at a constant temperature of $23.6( \pm 0.5)^{\circ} \mathrm{C}$ and $12 \mathrm{~h}$ light $/ 12 \mathrm{~h}$ dark photoperiod. The organisms were fed on a suspension of the small chlorophycean Pseudokirchneriella subcapitata, cultured in CHU 12 medium and cropped in the exponential phase, at a concentration of $10^{5}$ cells. $\mathrm{mL}^{-1}$, and $0.02 \mathrm{~mL}$ of a mixed suspension of yeast and fish ration added per organism (USEPA, 1994; ABNT, 2004) in equal proportions (1:1).

Fifty females with eggs were isolated and maintained until the production of neonates. Thirty neonates of less than 24 hours old were put in polypropylene bottles of $50 \mathrm{~mL}$ and kept in a germination chamber at the temperature, light and feeding conditions specified above. These organisms were observed daily to obtain the parameters of the life cycle.

The culture medium and food suspension was partially renewed every two days with a fresh suspension. This culture medium had $\mathrm{pH} 7.6$, conductivity 140 
$\mu \mathrm{S} . \mathrm{cm}^{-1}$ and hardness $46 \mathrm{mg} . \mathrm{L}^{-1}\left(\mathrm{CaCO}_{3}\right)$. Specimens of $C$. rectangula were deposited in the collection of the Laboratório de Limnologia, Universidade Federal de Alfenas (UNIFAL), in state of Minas Gerais.

Observations were made once a day to determine the size of the individuals, the number of eggs and longevity. To determine the embryonic development time, observations were made two or more times a day. The size of each individual was measured under a microscope using a micrometer and 40x magnification. The results of 40 observations were used for the embryonic development time determination and 25 observations for the individual size, age of primipara, longevity and fecundity.

The calculation of biomass was carried out according to EDMONDSON (1971), based on the mean body length and density of organisms in each size class (neonate, juvenile and adult). For the secondary production determination, the biomass increment method was used, based on WINBERG et al. (1965), using the sum of the daily increments in weight for each size class.

\section{RESULTS}

The identification and description of the $C$. rectangula species was carried out according to specialized literature, however, because this is a Palearctic species, it needs to be revised for specimens found outside this region. The species in this study has characteristics that differentiate it from the genus Coronatella and, after being reviewed, it can be relocated to a new genus.

The water bodies sampled in the global project were $C$. rectangula recorded are oligotrophic according to the trophic state index (Tab. I). Concentrations of dissolved oxygen ranged from 4.2 to $9.1 \mathrm{mg} \mathrm{L}^{-1}, \mathrm{pH}$ from 4.5 to 5.6 , electrical conductivity ranged from 30 to $193 \mu \mathrm{S} . \mathrm{cm}^{-1}$ and the mean water temperature was 23.5 $(5.7)^{\circ} \mathrm{C}$. The pond where the species was collected for culture (EPAMIG pond) is oligotrophic $(\mathrm{TSI}=27.7)$, with $\mathrm{pH}=5.3$, dissolved oxygen concentration of 9.1 $\mathrm{mg} \mathrm{L}{ }^{-1}$, electrical conductivity of $31 \mu \mathrm{S} . \mathrm{cm}^{-1}$ and water temperature of $12.2^{\circ} \mathrm{C}$.

Coronatella rectangula has a rectangular valve, straight ventral margin and evenly curved dorsal margin, and it may present longitudinal striations or tubercles arranged in rows. There are 30 to 40 marginal setae decreasing towards the posterioventral corner followed by small spinules. The head shield shows a rounded posterior margin; the ocellus is almost the same size as the eye; the keel of the labrum shows a convex anterior margin and the rostrum is short and rounded. Postabdomen is wide, dorsal margin S-shaped, anal margin slightly concave, with lateral spinules, 7 to 9 anal denticles, sometimes in groups and, in this case, the distal denticle is the largest. It has claws with a row of spinules on $3 / 4$ of the concave side and, near the base it shows two groups of fine spinules. Coronatella rectangula presents three head pores, typical of this species, which may help in identification (Figs 1-3).

The size of $C$. rectangula ranged from $195 \mu \mathrm{m}$ (neonate, lower measured value) to $468 \mu \mathrm{m}$ (Fig. 4). The neonates had a mean size of $204( \pm 30) \mu \mathrm{m}$, primipara $340( \pm 24) \mu \mathrm{m}$ and adults $434( \pm 14) \mu \mathrm{m}$ (Tab. II).

The embryonic development time of the specimens of $C$. rectangula (from observation of egg laying until spawning, in the incubator) was $1.68( \pm 0.13)$ days, and the time to reach primipara (the post-embryonic development time) was $2.48( \pm 0.45)$ days. The organisms examined achieved their maximum size after 18 days of age $(468 \mu \mathrm{m})$. The observed maximum longevity was 48 days and the average was $28.04( \pm 9.3)$ days.

The fecundity of parthenogenetic females was two eggs per brood; however, for two individuals in primipara the production of only one egg was observed and, for one individual, three eggs in the last generation. This individual died with one stunted egg and the others at an early stage of development.

During their life cycle, specimens had a maximum of 14 molts, and two instars for juvenile stage and a maximum of 12 instars for adult stage were observed.

The density registered was 140 individuals. $\mathrm{m}^{-3}$ : 70 adults and 50 juveniles. The total biomass in dry weight was $36.66 \mu \mathrm{gDW} \cdot \mathrm{m}^{-3}$ (9.83 for juvenile stage and $26.82 \mu \mathrm{gDW} \cdot \mathrm{m}^{-3}$ for adult biomass) and the secondary production $12.10 \mu \mathrm{gDW} . \mathrm{m}^{-3}$. day $^{-1}$ (8.34 for egg production and $3.76 \mu \mathrm{gDW} \cdot \mathrm{m}^{-3}$. day ${ }^{-1}$ for juvenile stage).

Tab. I. Chlorophyll $a(\mathrm{Chl})$, total phosphorus (TP), total dissolved phosphate (TDP) and Trophic State Index (TSI) for eight water bodies during the two study periods (TSI $<44=$ Oligotrophic).

\begin{tabular}{lcccccccc}
\hline & \multicolumn{2}{c}{ Chl } & \multicolumn{2}{c}{ TP } & \multicolumn{2}{c}{ TDP } & \multicolumn{2}{c}{ TSI } \\
& $\begin{array}{c}\text { Rainy } \\
\text { Period }\end{array}$ & $\begin{array}{c}\text { Dry } \\
\text { Period }\end{array}$ & $\begin{array}{c}\text { Rainy } \\
\text { Period }\end{array}$ & $\begin{array}{c}\text { Dry } \\
\text { Period }\end{array}$ & $\begin{array}{c}\text { Rainy } \\
\text { Period }\end{array}$ & $\begin{array}{c}\text { Dry } \\
\text { Period }\end{array}$ & $\begin{array}{c}\text { Rainy } \\
\text { Period }\end{array}$ & $\begin{array}{c}\text { Dry } \\
\text { Period }\end{array}$ \\
\hline Nova Floresta dam & 0.7 & 1.9 & 57.2 & 38.3 & 8.2 & 5.0 & 31.1 & 30.2 \\
Santo Antônio Pitangueiras pond & - & - & 50.3 & 69.6 & 5.1 & 7.9 & 22.1 & 24.8 \\
Santa Rita dam & 1.4 & 0.1 & 35.3 & 51.9 & 7.9 & 9.0 & 30.8 & 26.9 \\
Guaxupé pond & 1.4 & - & 32.7 & - & 9.4 & - & 31.3 & - \\
Paliteiro pond & 1.1 & 0.3 & 29.1 & 49.0 & 9.7 & 5.3 & 30.3 & 26.8 \\
CBA pond & - & - & 23.5 & - & 6.4 & - & 20.1 & - \\
Floresta Negra pond & - & - & - & 46.1 & - & 6.7 & - & 22.7 \\
EPAMIG pond & & 0.26 & - & 43.8 & - & 8.4 & - & 27.7 \\
\hline
\end{tabular}




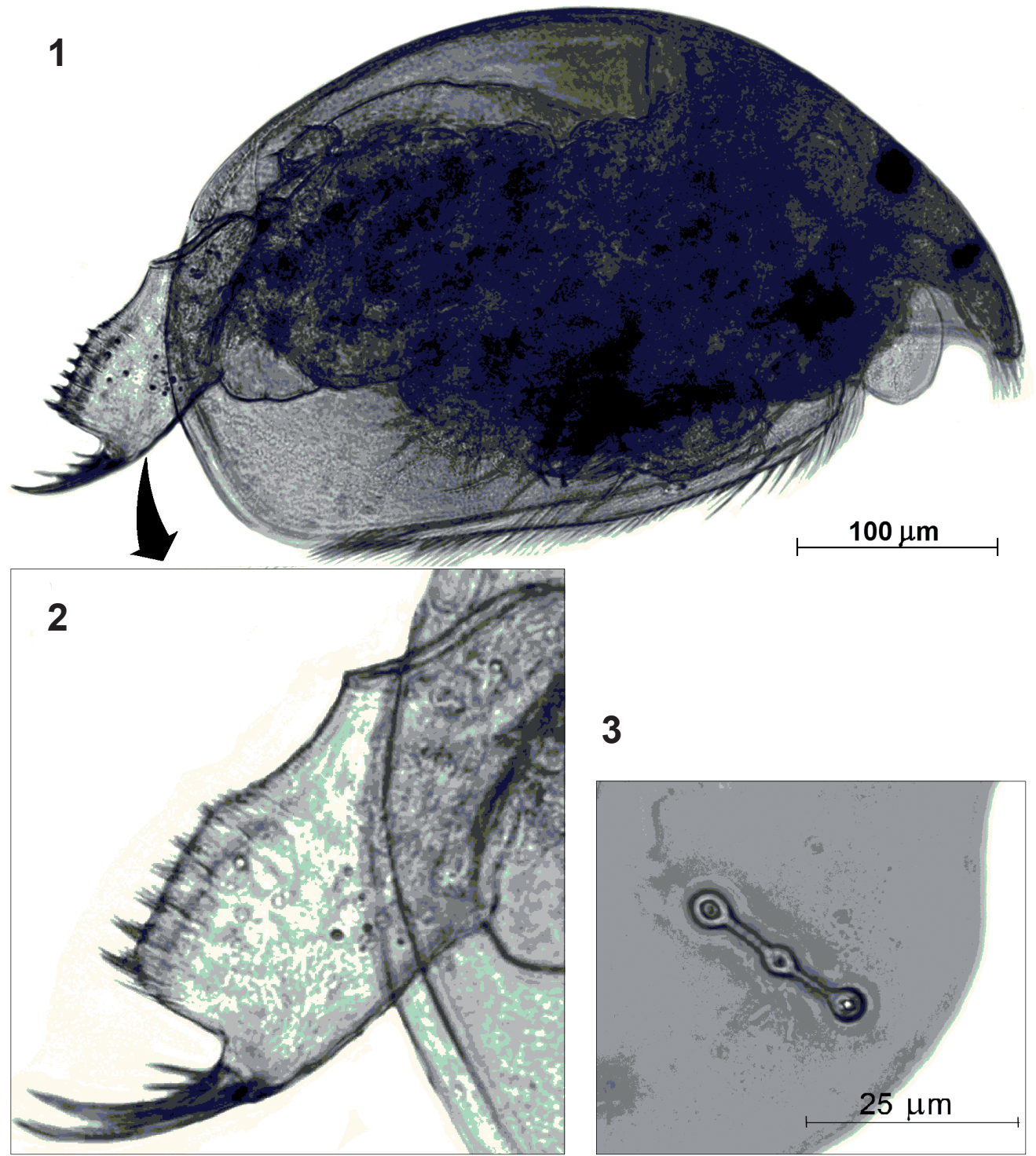

Figs. 1-3, Coronatella rectangula (Sars, 1861): 1, parthenogenetic female; 2, post-abdomen details; 3, head pore.

\section{DISCUSSION}

Coronatella rectangula is widely distributed in Brazil and specimens are found in states of São Paulo, Minas Gerais, Rio de Janeiro, Tocantins, Sergipe, Pará, Mato Grosso and Mato Grosso do Sul. In state of Minas Gerais, there were records of its occurrence in various water bodies of the basins of the Grande, Doce and São Francisco rivers (EskinaZI-SANT'ANNA et al., 2005; SANTOS-WISNIEWSKI et al., 2011).

In the present study, C. rectangula was recorded in a pond in the Lambari District (south of Minas Gerais). The pond is located in the Mantiqueira mountain range, a priority area for conservation because this environment provides heterogeneous habitats due to climatic gradients of sunlight, temperature and precipitation (DRUMMOND et al., 2005). This pond is shallow with large numbers of macrophytes and grasses around it. According to NANDINI et al. (2002), species such as C. rectangula are generally found associated with macrophytes of the littoral region. In the water bodies where $C$. rectangula were found, the water is well oxygenated and the $\mathrm{pH}$ tended to be acidic. High-altitude water bodies, such as this one in the Mantiqueira mountain range, generally tended to be acidic because of the peat soil that results from decomposition of alpine vegetation (FrançA \& Stehmann, 2004).

According to Kотоv (2006), some benthic Chydoridae or those associated with macrophytes may have adaptations related to their mode of life, such as incomplete molts, long rostrum, the sides of the body with flattened shape and setae on ventral margin of the valve. These structures may be found in $C$. rectangula and support locomotion in their natural habitat. The valve setae provide more adhesion to the substrate, such as leaves and stems of macrophytes. The flattened shape of the body facilitates locomotion and the long rostrum protects the head, the labrum and antennules from contact with large particles.

The maximum size $(468 \mu \mathrm{m})$ of $C$. rectangula 
Tab. II. Mean size $( \pm \mathrm{SD})$ and development times of Coronatella rectangula (Sars, 1861) (Cladocera, Chydoridae) from laboratory cultures at $23.6( \pm 0.5)^{\circ} \mathrm{C}, \mathrm{N}=30$.

\begin{tabular}{lc}
\hline Life cycle parameters & Values \\
\hline Maximum adult size $(\mu \mathrm{m})$ & 468 \\
Mean adult size $(\mu \mathrm{m})$ & $434(14)$ \\
Neonate mean size $(\mu \mathrm{m})$ & $204(30)$ \\
Primipara mean size $(\mu \mathrm{m})$ & $340(24)$ \\
Minimum size of primipara $(\mu \mathrm{m})$ & 273 \\
Number of instars between neonate and primipara & 2 \\
Maximum number of instars in the whole life cycle & 12 \\
Mean number of eggs in the whole life cycle & $27.8(9)$ \\
Mean fecundity (eggs/female/brood) & $1.98(0.24)$ \\
Maximum longevity (days) & 46 \\
Mean longevity (days) & $28.04(9.3)$ \\
Mean embryonic development time (days) & $1.68(0.13)$ \\
Primipara age (days) & $2.48(0.45)$ \\
\hline
\end{tabular}

is similar to the values found by SMIRNOv (1974), VAN DAMME et al. (2008) and ElMOOR-LOUREIRO (2010), who found that this species has a length up to $500 \mu \mathrm{m}$. This value was close to the $611.0( \pm 18.4) \mu \mathrm{m}$ registered for Acroperus harpae (MelÃo, 1999) and greater than the $389 \mu \mathrm{m}$ observed for Chydorus pubescens (SANTOSWISNIEWSKI et al., 2006). This difference occurs because the species of this study and Acroperus harpae belong to the Aloninae subfamily, which is usually longer, ranging from 350 to $1050 \mu \mathrm{m}$, while Chydorus pubescens belongs to the Chydorinae subfamily with length ranging from 270 to $600 \mu \mathrm{m}$.

The mean size of the C. rectangula neonate (204 $\mu \mathrm{m})$ was lower than that of Acroperus harpae (343 \pm $34 \mu \mathrm{m})$ (Melão, 1999) and Chydorus pubescens, which had a mean size of $242 \mu \mathrm{m}$ (SANTOS-WISNIEWSKI et al., 2006). According to Kотоv (1997), neonates of Chydorus sphaericus (O. F. Müller, 1776), Eurycercus lamellatus (O. F. Müller, 1785) and Bosmina sp. undergo a molt shortly after being released from the breeding chamber, which represents the first juvenile instar. In this study the first measurements of individuals were considered as neonate, although they may correspond to the first juvenile instar.

The results of the embryonic development time, primiparous age and longevity, for several Chydoridae species, were compared (Tab. III). The duration of post-embryonic development time is mainly affected by temperature and quality/quantity of food (HARDY \& Duncan, 1994). The embryonic and post-embryonic development time decrease when the temperature increases, as observed by several investigators (Bottrell, 1975; Freitas \& Rocha, 2006; Melão \& Rocha, 2006; SANTOS-WisNiEWsKi et al., 2006). This can be seen when the embryonic development times were compared between $C$. rectangula and other Chydoridae species from the literature.
The response for three species of tropical Cladocera to severe conditions, such as high temperatures and low food level, involves the increase in the number of juvenile instars, delaying the primiparous age and, consequently, increasing their longevity (HARDY \& DUNCAN, 1994). Melão \& Rocha (2006) observed that the postembryonic development time of Bosminopsis deitersi, raised under non-limiting food conditions, is highly temperature dependent. Nevertheless, primiparous age can be influenced by the quality and quantity of food (BotTrell et al., 1976). This was also observed in the present study, since $C$. rectangula, fed with algae and a mixed suspension of yeast and fish food, had a shorter duration of primiparous age than Chydorus dentifer and Acroperus harpae, which were fed only on algae (Melão, 1999).

The mean longevity of $C$. rectangula was 28 days, while SANTOS-WisniewSKI (2006) reported values close to this for Chydorus pubescens, grown under the same conditions of food, light and temperature. MelÃo (1999) recorded lower values for Chydorus dentifer (11.39 days at $25^{\circ} \mathrm{C}$ ) and this can be related to food quality, since the organisms were fed with the algal suspension only. The longevity of $C$. rectangula was much lower when compared to results obtained by BotTRELL (1975) for Acroperus harpae and by SHARMA \& Sharma (1998) for Alonella excisa, but these latter species were grown at a lower temperature, which may have decreased metabolism and thus interfered with longevity. The maximum longevity recorded for $C$. rectangula was close to that of Leydigia louisi mexicana, grown at $20^{\circ} \mathrm{C}$ and fed with Saccharomyces cerevisiae (MARTíNEZ-JERÓNIMO \& GómEZ-DíAz, 2010). Therefore, it can be observed that the longevity of the species can be increased or reduced depending on the nutritional and temperature conditions in cultivation (VIJVERBERG, 1989).

The Chydoridae typically has lower egg production than other families of Cladocera, such as Sididae and Daphnidae, which produce, in general, more than 3 eggs/

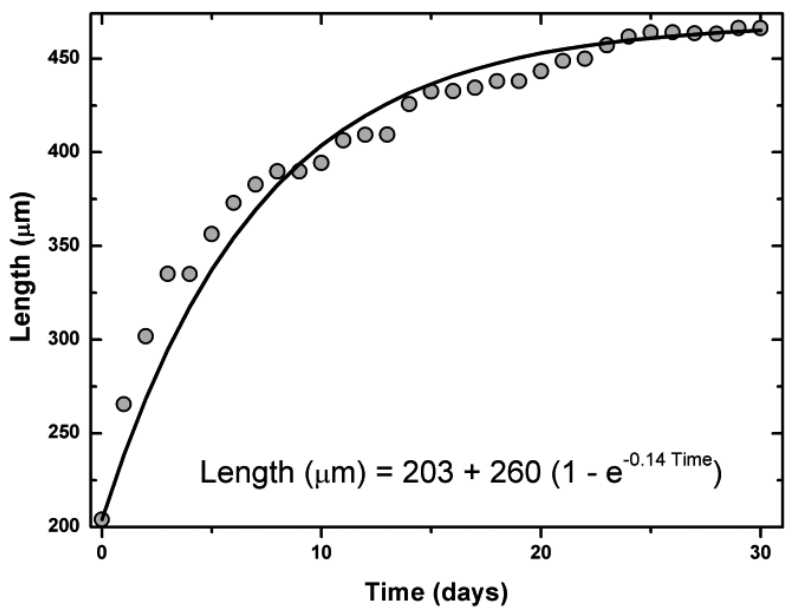

Fig. 4. Growth curve of Coronatella rectangula (Sars, 1861) with controlled light conditions (12 hours light/12 hours dark), temperature $\left(23.6 \pm 0.5^{\circ} \mathrm{C}\right)$ and food sources, in the laboratory. 
Tab. III. Comparison of embryonic development times and fecundity of chydorid cladocerans from the present study and reported in the literature [EDD, embryonic development duration (days); PA, primipara age (days); F, fecundity (eggs/female/brood); CF, cumulative fecundity (total number of eggs); L, longevity (days); T, temperature $\left.\left({ }^{\circ} \mathrm{C}\right)\right]$.

\begin{tabular}{|c|c|c|c|c|c|c|c|}
\hline Species & EDD & PA & $\mathrm{F}$ & $\mathrm{CF}$ & $\mathrm{L}$ & $\mathrm{T}\left({ }^{\circ} \mathrm{C}\right)$ & Author \\
\hline Coronatella rectangula & 1.68 & 2.48 & 1.98 & 27.8 & 28.04 & 23.6 & Present study \\
\hline Chydorus pubescens & 1.96 & 2.37 & 2 & 22.3 & 25.44 & 23.6 & SANTOS-WISNIEWSKI et al., 2006 \\
\hline Chydorus dentifer & 1.91 & 5.73 & 2 & & 11.39 & 25 & MeLÃo, 1999 \\
\hline Acroperus harpae & 1.56 & 3.7 & 1.59 & & 9.79 & 25 & MELÃo, 1999 \\
\hline Acroperus harpae & 3.18 & & & & 74 & 20 & BotTreLl, 1975 \\
\hline Alonella excisa & & 3.17 & 2 & 46 & 73.4 & 19 e 23 & Sharma \& Sharma, 1998 \\
\hline Leydigia acanthocercoides & & 3 & 2 & 20 & 23.2 & 28 e 30 & Murugan \& JoB, 1982 \\
\hline Leydigia ciliata & & & 2 & 50 & 46 & 28 e 30 & VenKataraman, 1990 \\
\hline Euryalona orientalis & & & 2 & 20 & 23.8 & 28 e 30 & VENKATARAMAN, 1990 \\
\hline
\end{tabular}

female/brood. Ceriodaphnia silvestrii produced around 9 eggs/female/brood (FonsECA \& RocHA, 2004), when observed in their natural environment, and Pseudosida ramosa produced around $3.4 \mathrm{eggs} /$ female/brood at $25^{\circ} \mathrm{C}$ and 4.3 eggs/female/brood at $30^{\circ} \mathrm{C}$ (Freitas \& RochA, 2006). The mean fertility of $C$. rectangula observed in this study was $1.98 \mathrm{eggs} /$ female/brood. This value is similar to the representatives of Chydoridae registered by other authors (2 eggs/female/litter) (MURUGAN \& Job, 1982; Sharma \& Sharma, 1998; Melão, 1999; SANTOS-WISNIEWSKI et al., 2006).

According to BotTrell (1975), the number of juvenile instars for Cladocera ranged from 3 to 8 . This value may be increased when food is limited, because organisms prioritize reproduction and take more time to reach adulthood (ODUM, 1988). In the present study, two juveniles or pre-reproductive instars were observed, also found for Chydorus pubescens (SANTOS-WISNIEWSKI et al., 2006) and Alonella excisa (Sharma \& Sharma, 1998). For Graptoleberis testudinaria (Fischer, 1851) and Chydorus sphaericus three molts were found in the juvenile stage, while for Acroperus harpae, Pleuroxus uncinatus and Alona affinis five instars and seven instars were found for Eurycercus lamellatus in the juvenile stage (BotTrell, 1975). Smirnov (1974), LynCH (1980) and VENKATARAMAN (1990) found one to three juvenile stages for some Chydoridae species, low values when compared to observed values for other Cladoceran families, which may have from two to seven stages. The number of prereproductive stages in this study is consonant with the low values already observed for this species, which suggests that the nutritional status and controlled conditions were good throughout the experiment.

In this study, 10 instars were observed in adults, a number closest to the 13 instars observed for Chydorus pubescens (SANTOS-WISNIEWSKI et al., 2006). However, the number of adult instars was lower than the values recorded for other species of Chydoridae, such as Leydigia acanthocercoides, 13 instars (MURUGAN \& JoB, 1982) and Alonella excise, 26 instars (SHARMA \& SHARMA, 1998). The highest number of recorded instars for Chydoridae was 49 instars (SMIRNov, 1974).
A high value was recorded for $C$. rectangula biomass (36.66 $\mu \mathrm{gDW} . \mathrm{m}^{-3}$ ) when compared to other studies, because the sampling was carried out in a shallow pond containing a large amount of macrophytes. This value is higher than that recorded by PANARELLI et al. (2010) for this species $\left(18 \mu \mathrm{gDW} . \mathrm{m}^{-3}\right)$ in Coqueiral pond, which is colonized by macrophytes and is a pond adjacent to the Paranapanema River, influenced by it through a connection between them. SANTOS et al. (2010) registered a much lower value for Alona verrucosa $\left(2.5 \mu \mathrm{gDW} . \mathrm{m}^{-3}\right)$, a species of the same family as $C$. rectangula. This difference in biomass may have occurred because in this study, and in that of PANARELLI et al. (2010), the samples were collected in ponds with macrophytes, while $A$. verrucosa was sampled in the limnetic region of a reservoir, where the occurrence of Chydoridae species is accidental. Secondary production of $C$. rectangula was also higher when compared to that recorded by PANARELli et al. (2010). The authors reported productivity of $3.3 \mu \mathrm{gDW} \cdot \mathrm{m}^{-3}$. day ${ }^{-1}$ in the Coqueiral pond, mostly contributed in the adult stage, which was also observed in this study.

Coronatela rectangula had higher productivity in the littoral region than the limnetic region, which indicates the importance of studies in the former region. From these data, studies will be performed on population dynamics, secondary production and food webs, which are essential for suitable management and preservation of these environments, mainly in the littoral region, which has been impacted by anthropic activities in aquatic ecosystems.

Acknowledgements. To Fundação de Amparo à Pesquisa do Estado de Minas Gerais (FAPEMIG) - BIOTA-MINAS APQ [0354909]; CRA- APQ [01518-09] and Eletrobrás Furnas P\&D Program [017138].

\section{REFERENCES}

ABNT - Associação Brasileira de Normas TéCniCAS. 2004. NBR 12713: Ecotoxicologia aquática - Toxicidade aguda - método de ensaio com Daphnia spp (Cladocera, Crustacea). Rio de Janeiro, ABNT. 21p.

Bottrell, H. H. 1975. Generation time, length of life, instar duration and frequency of moulting, and their relationship to temperature 
in eight species of Cladocera from the River Thames, Reading. Oecologia 19:129-140.

Bottrell, H. H.; Duncan, A.; Gliwicz, Z. M.; Herzig, A.; Hillbricht-Illkowska, A.; Kurasawa, H.; Larsson, P. \& WeGLENSKA, T. 1976. A review of some problems in zooplankton production studies. Norwegian Journal of Zoology 24:419-456.

Drummond, G. M.; Martins, C. S.; Machado, A. B. M; Sebaio, F. A. \& Antonini, Y. 2005. Biodiversidade em Minas Gerais: um atlas para sua conservação. Belo Horizonte, Fundação Biodiversitas. 222p

EDMONDSON, W. T. 1971. Methods for processing samples and developing data. In: Edmondson, W. T.; WinBerg, G. C. (Ed.). A manual on methods for the asement of secondary productivity in freshwaters. Oxford, Blackwell Scientific Publications. $357 \mathrm{p}$

Elmoor-Loureiro, L. M. A. 1997. Manual de identificação de cladóceros límnicos do Brasil. Brasília, Universa. 156p.

2000. Brazilian cladoceran studies: where do we stand? Nauplius 8:117-131.

2007. Phytophilous cladocerans (Crustacea: Anomopoda and Ctenopoda) from Paranã River Valley, Goiás, Brazil. Revista Brasileira de Zoologia 24:344-352.

2010. Cladóceros do Brasil: Famílias Chydoridae e Eurycercidae. Available at $<\mathrm{http} / / /$ cladocera.wordpress.com/ $>$. Accessed on 8.06.2012

Eskinazi-Sant'anna, E. M.; Maia-Barbosa, P. M.; Brito, S. L. \& RieTzLeR, A.C. 2005. Zooplankton biodiversity of Minas Gerais State: a preliminary synthesis of present knowledge. Acta Limnologica Brasiliensia 17:199-218

FonsecA, A. L. 1998. The life cycle of Ceriodaphnia silvestrii (Daday 1902) and Daphnia laevis (Birge, 1878) (Crustacea, Cladocera) reared under different $\mathrm{pH}$ conditions. Verhandlungen Internationalen Verein Limnologie 26:1918-1921.

FonsecA, A. L. \& Rocha, O. 2004. The life cycle of Ceriodaphnia silvestrii Daday, 1902, a Neotropical endemic species (Crustacea, Cladocera, Daphnidae). Acta Limnologica Brasiliensia 16:319-328.

Forró, L.; Korovichinky, N. M.; Kotov, A. A. \& Petrusck, A. 2008. Global diversity of cladocerans (Cladocera; Crustacea) in freshwater. Hydrobiologia 595:177-184.

França, G. S. \& Stehmann, J. R. 2004. Composição florística e estrutura do componente arbóreo de uma floresta altimontana no município de Camanducaia, Minas Gerais, Brasil. Revista Brasileira de Botânica 27:19-30.

Freitas, E. C. \& Rocha, O. 2006. The life cycle of Pseudosida ramosa, Daday 1904, an endemic Neotropical cladoceran. Acta Limnologica Brasiliensia 18(34):293-303.

Golterman, H. L.; Clymo, R. S. \& Ohnstad, M. A. M. 1978. Methods for physical and chemical analysis of freshwaters. Oxford, Blackwell. 213p.

Guntzel, A. M.; Matsumura-Tundisi, T. \& Rocha, O. 2003. Life cycle of Macrothrix flabelligera Smirnov, 1992 (Cladocera, Macrothricidae), recently reported in the Neotropical region. Hydrobiologia 490:87-92.

HARDY, E. R. \& DUCAN, A. 1994. Food concentration and temperature effects on life cycle characteristics of tropical Cladocera (Daphnia gessneri Herbst, Diaphanosoma sarsi Richard, Moina reticulata Daday): I. Development time. Acta Amazonica 24:119-34.

Keppler, E. C. \& Hardy E. R. 2002. Estimativa do tamanho das fêmeas com ovos de Moina minuta Hansen, 1899 (Cladocera, Crustacea) no lago Amapá, Rio Branco, Estado do Acre, Brasil. Acta Scientiarum 24(2):321-328.

Koтov, А. А. 1997. A special moult after the release of the embryo from the brood pouch of Anomopoda (Branchiopoda, Crustacea) a return to an old question. Hydrobiologia 354:83-87.

. 2006. Adaptations of Anomopoda Crustaceans (Cladocera) to the benthic mode of life. Entomological Review 85:210-225.

LyNCH, M. 1980. The evolution of cladoceran life histories. Quarterly Review of Biology 55:23-42.

Maia-Barbosa, P. M. \& Bozelli, R. L. 2006. Community structure and temporal dynamics of cladocerans in an Amazonian lake (lake Batata, PA, Brazil) impacted by bauxite tailings. Acta Limnologica Brasiliensia 18:67-75.

MartíneZ-Jerónimo, F. \& GómeZ-Días，P. 2010. Reproductive biology and life cycle of Leydigia louisi mexicana (Anomopoda, Chydoridae), a rare species from freshwater littoral environments. Crustaceana 84(2): 187-201.
MeLÃo, M. G. G. 1999. Desenvolvimento e aspectos reprodutivos de cladóceros e copépodos de águas continentais brasileiras. In: PompÊo, M. L. M. Perspectivas da Limnologia no Brasil. São Luis, Gráfica e Editora União. 15p.

Melão, M. G. G. \& Rocha, O. 2006. Life history, population dynamics, standing biomass and production of Bosminopsis deitersi (Cladocera) in a shallow tropical reservoir. Acta Limnologica Brasiliensia 18(4):433-450.

Murphy, J. \& Riley, J. P. 1962. A modified single solution method for the determination of phosphate in natural waters. Analytica Chimica Acta 27:31-36.

Murugan, N. \& Job, S. V. 1982. Laboratory studies on the life cycle Leydigia acanthocercoides Fisher (1854) (Cladocera: Chydoridae). Hydrobiologia 89:9-16.

Nandini, S.; Muro-Cruz, G. \& Sarma, S. S. 2002. Competition between littoral cladocerans Macrothrix triserialis and Alona rectangula (Cladocera) in relation to algal food level and inoculation density. Acta Hidrochimica et Hydrobiologica 30:16-23.

Nogueira, M. G.; George, D. G. \& Jorcin, A. 2003. Estudo do zooplâncton em zonas litorâneas lacustres: um enfoque metodológico. In: HenRY, R. ed. Ecótonos nas interfaces dos Ecossistemas Aquáticos. São Carlos, Editora Rima. 360p.

Odum, E. P. 1988. Ecologia. Rio de Janeiro, Guanabara Koogan. 434p.

Panarelli, E. A.; Casanova, S. M. C. \& Henrr, R. 2010. Secondary production and biomass of Cladocera in marginal lakes after recovery of their hydrologic connectivity in a river-reservoir transition zone. Lakes \& Reservoirs: Research and Management 15:319-334.

Rietzler, A. C. 1998. Tempo de desenvolvimento, reprodução e longevidade de Diaphanosoma birgei Korinek e Ceriodaphnia silvestrii Daday em condições naturais de alimentação. Anais do VIII Seminário Regional de Ecologia 8:1159-1171.

Rocha, O. \& Matsumura-Tundisi, T. 1990. Growth rate, longevity and reproductive performace of Daphnia laevis Birge, D. gessneri Herbst and $D$. ambigua Sfield in laboratory cultures. Revista Brasileira de Biologia 50:915-921.

Santos, M. A. P. F.; Melão, M. G. G. \& Lombardi, A. T. 2006. Life history characteristics and production of Ceriodaphnia silvestrii Daday (Crustacea, Cladocera) under different experimental conditions. Acta Limnologica Brasiliensia 18(2):199-212.

Santos, R .M.; Negreiros, N. F.; Silva, L.;C.; Rocha, O. \& SAntosWISNIEWSKI, M. J. 2010. Biomass and production of Cladocera in Furnas Reservoir, Minas Gerais, Brazil. Brazilian Journal of Biology 70(3):879-887.

SAntos-Wisniewski， M. J.; Rocha, O.; Guntzel, A. M. \& Matsumura-Tundisi, T. 2002. Cladocera Chydoridae of high altitude water bodies (Serra da Mantiqueira) in Brazil. Brazilian Journal of Biology 62(4):681-687.

Santos-Wisniewski, M. J.; Rocha, O. \& Matsumura-Tundisi, T. 2006. Aspects of the life cycle of Chydorus pubescens Sars, 1901(Cladocera, Chydoridae). Acta Limnologica Brasiliensia 18(3):305-310

Santos-Wisniewski, M. J.; Matsumura-Tundisi, T.; Negreiros, N. F.; Silva, L. C.; Santos, R. M. \& Rocha, O. 2011. Present knowledge on Cladocera (Crustacea, Branchiopoda) of fresh waters in Minas Gerais State. Biota Neotropica 11(3):287-301.

Sharma, S. \& Sharma, B. K. 1998. Observations on the longevity, instar durations, fecundity and growth in Alonella excisa (Fisher) (Cladocera, Chydoridae). The Indian Journal of Animal Science 68:101-104.

Sinev, A. Y. 2001. Separation of Alona cambouei Guerne \& Richard, 1893 from Alona pulchella King, 1853 (Branchiopoda: Anomopoda: Chydoridae). Arthropoda Selecta 10(1):5-18.

Smirnov, N. 1974. Chydoridae fauna USSR. Nauk, Leningrad, Zoological Institute Academy. 664p.

Soares, C. E. A. \& Elmoor-Loureiro, L. M. A. 2011. An updated checklist of Cladocera (Crustacea: Branchiopoda) from Pernambuco State, Brazil. Biota Neotropica 11(2):1-6.

Sousa, F. D. R. \& Elmoor-Loureiro, L. M. A. 2008. Phytopilous cladocerans (Crustacea, Branchiopoda) of the Parque Nacional das Emas, State of Goiás. Biota Neotropica 8(1):159-166.

Toledo, A. P.; Talarico, M.; Chinez, S. J. \& Agudo, E.G. 1983. A aplicação de modelos simplificados para avaliação do processo de eutrofização em lagos e reservatórios tropicais. In: Anais do Congresso Brasileiro de Engenharia Sanitária e Ambiental $33 p$. 
USEPA 1994. Methods for measuring the toxicity and bioaccumulation of sediment-associated contaminants with freshwater invertebrates. Report EPA 600/R-94/024. Duluth, United States Environmental Protection Agency. 133p.

Van Damme, K. \& Dummont, H. J. 2008. Further division of Alona Baird, 1843: separation and position of Coronatella Dybowski \& Grochowski and Ovalona gen. n. (Crustacea: Cladocera) Zootaxa 1960: 1-44.

Van Damme, K.; Kotov, A. A. \& Dummont, H. J. 2010. A checklist of names in Alona Baird 1843 (Crustacea: Cladocera: Chydoridae) and their current status: an analysis of the taxonomy of a lump genus. Zootaxa 2330:1-63.
Venkataraman, K. 1990. Life-history studies on some cladoceran under laboratory conditions. Journal and Science Association 6:127-132.

ViJVERBERG, J. 1989. Culture techniques for studies on the growth, development and reproduction of copepods and cladocerans under laboratory and in situ conditions. Freshwater Biology 21:317373.

Winberg, G. C.; Pechen, G. A. \& Shusshinina, E. A. 1965. Production of planktonic crustaceans in three lakes of different type. Zoologichesky Zhurnal 44:676-687. 